\title{
Reality education: Agricultural knowledge exchange in the U.S. South
}

\author{
Sarah Franzen* \\ Emory University
}

Submitted October 20, 2016 / Revised March 2 and March 17, 2017 / Accepted March 17, 2017 /

Published online March 29, 2017

Citation: Franzen, S. (2017). Reality education: Agricultural knowledge exchange in the

U.S. South. Journal of Agriculture, Food Systems, and Community Development, 7(2), 69-83.

http://dx.doi.org/10.5304/jafscd.2017.072.013

Copyright (C) 2017 by New Leaf Associates, Inc.

\begin{abstract}
Access to agricultural education is critical for farmers to maintain sustainable and profitable agricultural enterprises. Yet African American farmers have historically faced obstacles in gaining equal access to educational resources, due in part to the communicative frameworks through which agricultural knowledge is transmitted. Framing agricultural education as a communicative event, this paper examines the process of knowledge transmission itself as practiced by a grassroots organization dedicated to overcoming educational disparities by providing educational programs and resources for African American farmers. This paper draws on research gathered through ethnographic methods, including collaborative filmmaking. Collaborative filmmaking provided both a means to focus on the performative, tacit,

* Sarah Franzen, Research Associate, Masters in Development Practice Program, Emory University, Atlanta, Georgia; +1-404-957-8400; sarfranzen@gmail.com
\end{abstract}

and embodied components of the educational process and a tool for discussing interpretations and the relevance of the educational programs with participants. Drawing on this research, this paper argues that while it is important for all extension agents and educators to pay attention to communicative frameworks, intermediary organizations play an important role in providing critical and accessible agricultural education to local communities. Intermediary organizations and local educational programs can utilize local discourses, engage tacit and symbolic knowledge, serve as translators between mainstream educational resources and local communities, and provide specific knowledge for the goals of local communities.

\section{Keywords}

Race; Education; Community Development; Beginning Farmer; Social Justice; Community Engagement; Experiential Learning; Cooperatives; Smallholder Agricultural Programs 


\section{Introduction}

Agricultural education is a crucial component of the agricultural system; in the United States, educational programs for farmers have been critical in shaping the trajectory of farmers' techniques, approaches, and livelihoods. Yet the country's mainstream educational and extension programs have also caused and exacerbated injustices within the agricultural system. In particular, African American farmers have faced a long history of discrimination from both the U.S. Department of Agriculture (USDA) and university extension programs (Daniel, 2013; Grim, 1996; Harris, 2008; Jones, 1994; also see information on Pigford v. Glickman in Cowan \& Feder, 2011; Glickman, Rominger, \& Reed, 1997). ${ }^{1}$ Racial discrimination in access to knowledge and resources has significantly affected African American farmers' abilities to compete within the agricultural sector, leading to a drastic decrease in African American farmers throughout the twentieth century (Wood \& Gilbert, 2000). However, overt discrimination against African American farmers is not the only obstacle to accessing agricultural knowledge. Educational practices are embedded within ideological, communicative, and systemic frameworks that shape the process of knowledge transfer. In this paper, I focus specifically on the process of knowledge transmission itself by framing education as a communicative event. This paper draws on examples of educational events organized by a grassroots civil rights organization, the Federation of Southern Cooperatives/Land Assistance Fund (hereinafter called the Federation).

Founded in 1967, the Federation is a regional network dedicated to supporting and promoting rural development through cooperative principles applied to building land-based economic enter-

\footnotetext{
1 The second Morrill Act (1890) provided additional funds to each state with the stipulation that African Americans were to be admitted to land-grant institutions; states could alternatively use the funds to create separate colleges for African Americans, which happened throughout the Southern states. Despite this effort, African American farmers, and these 1890 land-grant colleges, have historically received less funding and been denied equal access to government agricultural resources (Daniel, 2013; Harris, 2008; Hart, 2001; Whayne, 1998).
}

prises (Federation of Southern Cooperatives/Land Assistance Fund [FSC/LAF], n.d.). While the Federation's focus is to support African American farmers and rural residents, it extends its services and support to all family farmers, regardless of race. Currently, the Federation consists of over 70 active cooperative groups with a membership of more than 20,000 families across 10 Southern states, with field offices in Mississippi, Alabama, and Georgia (FSC/LAF, n.d.). Its administrative headquarters in East Point, Georgia, serve as the public face of the Federation to conduct fundraising, policy work, and national and international relationship building.

Since the beginning, the Federation ${ }^{2}$ has focused on education as a crucial component of rural development. The organization seeks to address gaps in the educational needs of African American farmers in two main ways. First, it has helped African American farmers gain access to existing educational resources by connecting farmers to extension agents; helping African American farmers understand and apply for government programs, loans, and grants; and providing resources to help farmers attend workshops and field days at agricultural universities. Second, the Federation has created its own educational programs that teach not only agricultural techniques, but also cooperative development, small farm business training, estate planning, and land retention strategies, among other topics. The Federation has made more accessible both centralized and decentralized and formal and informal educational programs that work with farmers and rural residents both in groups and on an individual basis.

The Federation has also recognized the need for localized educational programs. The Federation has organized its member cooperatives into State Associations, each of which can better assess and meet the educational needs of its member cooperatives and farmers (Zippert, 1979). State Association staffs provide individual on-farm assistance,

\footnotetext{
${ }^{2}$ During my research, the majority of farmers and Federation members I interviewed cited education as one of their main reasons for joining the Federation or one of its member cooperatives.
} 
attend cooperative members' meetings, and provide workshops and trainings for members. These workshops typically incorporate presentations from local extension agents, university researchers, or other experts, thus combining multiple forms of education for participants. At an even more localized level, cooperatives themselves also provide education and training for their members. These processes vary largely from cooperative to cooperative and depend on the needs and goals of the members. On the whole, most of these educational processes involve farmer-to-farmer-style training, through which members teach each other about what is working (or not) on their own farms.

In this paper, I explore an informal educational encounter and two educational programs, one implemented by a State Association and the other by a cooperative. First, I examine an informal moment of knowledge exchange between an established vegetable cooperative in Mississippi and a newly forming vegetable cooperative in Louisiana. This informal meeting between cooperative members is a common benefit for Federation members throughout the network and serves as an example of local and informal communicative frameworks among the membership. I compare this encounter to two educational programs. The first event was an on-farm goat demonstration hosted by the president of the Southeastern Goat Cooperative (SoGoCo). The goal of this workshop was to increase farmers' familiarity with goats in order to encourage others to try raising goats, and thus increase the membership of the cooperative. The second event was a two-day tour and workshop for beginning farmers conducted by the Mississippi Association of Cooperatives (MAC), the Federation's Mississippi State Association. This event was intended to fill what MAC staff saw as a gap in the knowledge of beginning and potential farmers. Before exploring these cases in depth, I first provide a background framework used to theorize these as communicative events and the methodology used to collect the data on each case study. Finally, I conclude with a discussion on lessons learned and recommendations.

\section{Background on Communicative Frameworks} Communicative events in agricultural education consist of shared times and spaces that rely on shared communicative practices and meta-communicative frameworks. This process is not just a transfer of information, but is itself generative of and dependent upon existing social, cultural, and political structures (Sherzer, 1987). A key aspect in considering the success of educational efforts is the communicative competency of participants (Hymes, 1985). Even among participants sharing a language, differences in accent, dialect, syntax, word choice, sentence structure, and idioms can all affect how information is understood and perceived. Specialized extension agents utilize a different discourse than farmers due to the nature and effect of formalized and academic training. Language gaps also exist due to diverse cultural and social differences in language use. Farmers are often expected to code-switch to professionalized discourse, even though they may lack formal training in such discourse.

In addition to verbal language, body posture, position, gesture, and expressions all assist in the construction of communication (Streeck, Goodwin, \& LeBaron, 2011). This performative aspect of communication also serves to construct identity not only for the performer, but also for the audience, especially in situations of unequal power dynamics. Identity is more than an internal conceptualization of self; it is relationally produced through discourse and practices (Bucholtz \& Hall, 2005). This production is informed by both macroand microlevel socio-cultural contexts, which position people within identity frameworks. Thus, communicative events position audiences or listeners within specific subject positions. Charles Briggs (2005) proposes the use of "communicability" to refer to the productive capacity of language in creating subjective identities. Communicability creates domains that seem unified, position people within discourses, and produce forms of self-regulation among people who want to participate. These communicability spheres are spaces of knowledge production, reproduction, dissemination, and transmission. Those who can correctly engage in these communicability spheres through correct forms of discourse and subject positioning can access forms of knowledge and power associated with these spheres (Briggs, 2005). 
But those who are unable to correctly engage in the proper form of communicability, either because of their communicative skills or subject position, are excluded from knowledge and resources governed within the sphere.

The Federation works to disrupt communicability spheres that have historically discriminated against African American farmers. The historic segregation and discrimination against African American farmers built a pattern of communicative interactions between extension agents and African American farmers that reproduces racialized power dynamics. Even with shifting laws and practices that promote racial inclusion and integration, African American farmers tend not to have the communicability patterns to access power and resources. Federation staff address these issues in two ways: first, they attempt to translate, and thus help African American farmers access mainstream communicative spheres. Second, they create alternative forms of extension, built on communicability of African American farmers using their network as a means for farmers to educate each other.

The process of knowledge transmission also involves nondiscursive forms of knowledge, sometimes referred to as implicit understanding (Shotwell, 2011) or tacit knowledge (Polanyi, 1966). This form of knowing includes skills and practices used in farming, observational awareness of sensory cues, and affective understanding, which rely on the farmers' physical presence and interaction with the ecological and social environments (Csordas, 1993). It also includes modeling what it means to be a farmer, and the ability to evaluate what is a good farmer, or symbolic knowledge (Burton, 2004). Federation staff and members often emphasize the importance of familiarizing youth with the sensory experience of farming in order to instill an appreciation and a tacit understanding of agriculture. By positioning educational events on farms and using hands-on techniques, the Federation's educational programs engage in tacit forms of knowledge transfer. Additionally, the process of using established African American farmers as educators not only provides practical knowledge for other farmers, but also models an image of what it means to be an African American farmer. Tacit knowledge affects farmers' ability to develop crucial skills and adapt to ever-changing environments. Symbolic knowledge shapes farmers' identity and social relationships.

Knowledge transmission may also be obstructed because the type of knowledge being communicated does not fit paradigmatically into the cultural, social, ecological, or economic agricultural systems of the learning participants. Given that knowledge is embedded within ideological and paradigmatic frameworks, promoting particular agricultural techniques results in the enforcement of particular agricultural systems. Therefore, while innovative agricultural techniques may present efficient methods for increasing production, they may not be suitable for small-scale farmers, parttime farmers, or farmers with mixed landscapes. Or they may simply not fit with the specific goals and desires of particular farmers. The goal for the Federation is to help farmers understand, evaluate, and utilize diverse forms of knowledge to determine which techniques are most appropriate for their systemic goals of agriculture.

Together, these aspects are important considerations for creating effective educational programs. Communicability spheres within agricultural education establish normalized discourses and subject positions that govern access to knowledge and information and promote particular values or systematic frameworks. The Federation serves an important role in facilitating agricultural education for African American farmers and helps navigate the gaps in communicability spheres between African American farmers and mainstream educational resources.

\section{Methodology}

This paper draws on my ethnographic research conducted with the staff, organizers, and farmers involved with the Federation in Alabama, Mississippi, and the administrative headquarters in East Point, Georgia, conducted between 2011 and 2013. My research takes a community-based approach using interviews, informal conversations, participant observation, oral histories, archival research, and, most prominently, ethnographic filmmaking. Drawing on a framework of reflexive science (Burawoy, 1998), I approach filmmaking as a collaborative and intersubjective process of shared 
time and space (Fabian, 2001) through which individuals and groups can directly express cultural and subjective identities and then collaboratively discuss and interpret the material that was filmed. The ethnographic value derived from this method resides not simply in the films but in the process and social interactions surrounding their production and viewing. In my research, this process is a repetitive practice in what I term adaptive coproduction. This approach to filmmaking combines observational and participatory techniques.

Observational filmmaking emphasizes a material, phenomenological, and relational understanding of culture (Grimshaw \& Ravetz, 2009; MacDougall, 2006; Young, 2003), providing a means to focus on specific manifestations of social and cultural patterns at a given moment (MacDougall, 1998), while privileging the visual, sensory, and particular over the abstract and general (Grimshaw \& Ravetz, 2009). Filming in this manner is more active than simply witnessing an event. It requires an observational stance (Grimshaw \& Ravetz, 2009) or way of looking (MacDougall, 2006) in which the researcher continually selects to focus on, and film, moments of meaning as they unfold through social interactions. Filming observationally is a skilled practice of being present in the moment and responding to relationships and situations happening in front of the camera (Grimshaw \& Ravetz, 2009; MacDougall, 2003; Rouch, 2003).

This form of filming also requires an intimate relationship with the films' subjects (Young, 2003). In order to understand the significance of ongoing gestures, utterances, and movements, and to accurately select among various foci, the researcher must be familiar with the participants appearing before the camera. Furthermore, the participants need to have a certain level of comfort and trust in order to engage with the filmmaker. Observational cinema can be seen as a form of filmmaking in which the filmmaker shares the subjects' experiences and in turn shares these experiences with audience members. The resulting film remains open, never fully determining the complete interpretation of the moment on the screen, thus allowing the viewers their own experience of the situation as it unfolds.
While observational cinema implies a relationship between filmmakers and film subjects, participatory filmmaking makes the relationship explicit (MacDougall, 2003). Participatory filmmaking considers that the solicitation and provocation brought forth by filmmaking reveals the identities, culture, and relationships that the researcher is exploring. This process can be used to encourage performances and enactments (Rouch, 2003; Sjöberg, 2008) and collaborative or participatory projects in which participants use the camera to express and record their own perspectives (Dienderen, 2007; Elder, 1995; Flores, 2007). Similarly, my project sought explicit input from the filmed participants. Federation staff and members worked collaboratively with me to determine the process of filmmaking and decide which events or moments should be filmed. Footage was then screened back to participants in order to solicit feedback. Edited versions of different events were circulated within the cooperative networks of the Federation. Through these interactions, the ethnographic significance was more than just the films themselves, as it included all the interactions and discussions around the production of the films.

The process of collaboration and the method of filmmaking also assisted me in learning and accessing local forms of communication. As a white, Northern-born doctoral student, I occupied different communicative spheres compared to the participants in this research. My ethnographic approach and participant observation provided me both exposure to local forms of communication and the time needed to learn and participate within these communicative spheres. But even more significantly, by creating a collaborative filmmaking project, I positioned the filming process as not simply a method for my research, but as a tool for facilitating and building media communication among and for the Federation's network. Communication with the camera, therefore, was intended not only for me, but also for other anticipated audiences that included other Federation members, the Federation's administrative staff, and possibly other Federation supporters. This process of collaborative filmmaking positioned me at the center of communicative processes that existed among members, as well as 
between participants and anticipated larger audiences. Additionally, the method of filmmaking provided me a means to repeatedly watch and observe the process of communication recorded by the camera. This repeated and detailed exposure to participants' communication allowed me to develop a deeper understanding of local communicability.

This paper is based on a close examination of the communicability within two filmed educational events conducted by Federation members. The two films described here were created upon invitation from the participants. Longer versions were shown to the participants and at cooperative meetings. At these screenings, participants discussed their interpretations of the filmed events and determined which parts were most significant. After these discussions, I further edited the films and rescreened them.

Along with these two examples of educational programs, I also provide a close reading of a visit from members of a newly formed cooperative to an established cooperative, which was also filmed. This informal visit was not an official part of the educational programming of the Federation, but it is an example of a common way in which members learn from each other. I use this example as a way to demonstrate how the formal educational programs draw from and mimic informal communicability spheres as well as showcase how education exists beyond the formally organized programs.

The educational events were evaluated according to the style of communication used by presenters, the communicability spheres or subject positions imposed within the communicative event, the tacit and symbolic knowledge present in the educational event, and the systemic frameworks supported by the knowledge being presented at the educational events. Further insights into the material were gathered through the discussions around the screenings; informal conversations before, during, and after the educational events; and interviews conducted with participants and educators outside of the educational events. I also attended and filmed workshops and trainings by USDA extension agents and university researchers with the African American farmers participating in my research and was present when extension agents conducted site visits on participants' farms. The films described here were compared to my filmed material of the informal educational exchanges between cooperative members and my filmed material of presentations by agricultural extension agents and university researchers.

\section{Results}

\section{Cooperative Visit}

One way that Federation members gain agricultural knowledge is through learning from other members within the network. This is especially pertinent for farmer cooperatives in the process of organizing or expanding. In order to facilitate crosscooperative learning, many on-farm and cooperative visits are organized into workshops and meetings within the Federation, but informal visits are frequent as well. During my research with the Indian Springs Farmers Association, located outside Petal, Mississippi-one of the oldest Mississippi member cooperatives-members from a newly formed farmer cooperative in Louisiana came to see Indian Springs' vegetable processing shed. The visit and tour were facilitated by the director of the Federation's Mississippi branch, a second-generation member of Indian Springs, and one of the regular coordinators of Indian Springs. As part of my research, I had established an ongoing collaborative film project with Indian Springs and was present to film events such as this visit.

The visit began with a tour around the processing facilities. The facilitator demonstrated how they cleaned, packaged, stored, and boxed produce. This included detailed information about the prices and funders for some of the machines and equipment, and simple advice, such as the benefit of using wooden crates over cardboard in order to preserve the freshness of produce. The tour was casual and informal, with fluid and meandering conversation. The visitors touched and examined the various tools, equipment, and materials used within the process.

The facilitator then set up a circle of chairs for the four Louisiana visitors and the two Indian Springs members. The six men sat in an open, equal, and conversational manner with no formal leader or presentation. Dialogue ebbed and 
meandered casually, at times interrupted as the facilitator got up to grab a label used to package okra or one of the slips they give to farmers who bring in produce, or to attend to an unrelated errand. This style of communicating emulated the form and structure of a social visit, rather than a formal educational event. The facilitator only guided the conversation, leaving at times to bring in a prop or to attend to business, and allowing all participants to equally participate and contribute to the conversation.

The facilitator's style of conversation positioned the participants as equals within the communicative framework. His casual body position, storytelling, informal dialogue, and use of vernacular dialects and idioms positioned all the men on an equal level with a shared investment in the ongoing conversation. Even though the Louisiana cooperative had travelled to learn from Indian Springs, all of those present added to the dialogue and contributed their own insights and understanding.

The casual and equal style of communication in turn supported a wide number of topics that blended different forms of knowledge and understanding, such as planting seasons, crop prices, and the nature of contracts with different distributors and retailers, including Walmart and Whole Foods. The men exchanged tips and techniques, including traditional agricultural practices passed on from parents and grandparents. They also told stories about their various experiences and trials with farming.

While the discussion focused on improving productivity, the purpose for this improvement was not for economic gain alone. The Louisiana men discussed their goal to use farming as a supplemental form of income. Through farming, rural residents could simultaneously build a more sustainable income, secure their residency on farms, and continue a livelihood and way of life that is increasingly being threatened by the industrial agricultural system. The men also discussed the importance of maintaining a farming tradition within their communities. These values-maintaining a way of life, a set of traditions, and rural residency - are sometimes beyond the scope of typical agricultural extension concerns, so farmers are not provided useful knowledge for establishing small-scale and part-time farming enterprises. But for many Federation members, these values are the reasons for pursuing agricultural enterprises.

The casual nature of the conversation emphasized personal and social connections between the men, allowing for local colloquiums and meanings to enter into the conversation. While educational workshops are often designed as rapid, structured, linear dispersions of data, nothing was orderly about this setting. The conversation contained key nuggets of critical and relevant knowledge about how to better grow and market vegetables, but these pieces of data were surrounded by stories that were both relevant and tangential to the information. Knowledge remained contextualized within its narrative framing, requiring visitors to attend to both technical data points and the surrounding details. These elements bound the knowledge within social conventions and facilitated a familiarity among the men.

After their conversation, the men continued their tour through the facilitator's fields. They examined and handled some of Indian Springs' more advanced equipment, including a planter and transplanter. On the farm they watched the facilitator demonstrate his automated irrigation device. These hands-on opportunities gave the visitors a chance to look at, feel, and sense the equipment, the fields, and the crops. This type of sensory engagement with Indian Springs' farming operations was perhaps too short to convey in-depth tacit knowledge, but it nonetheless offered the visitors a chance to expand their understanding of the operations through an embodied experience.

The significance of this event is its resistance to de-contextualization. Relevant information was exchanged through channels within a communicative framework common to social visits, informal encounters, and daily activities. ${ }^{3}$ The casual, slow, and meandering form of conversation was only

\footnotetext{
${ }^{3}$ The commonality of the communicative style was determined based on comparisons to additional filmed material of social, daily, and informal events, as well as participant observation. The usefulness of this encounter was later discussed in informal conversations with the Louisiana cooperative members at an annual meeting of Federation members.
} 
one component to this communicative style. Additionally, topics of conversation, body language, and the framing of technical knowledge within politicaleconomic knowledge all were part of the metacommunicative exchanges between cooperative members.

\section{Goat Workshop 4}

In late November 2012, the president of the Southeastern Goat Cooperative of Alabama (SoGoCo) invited members, Federation staff, family, friends, and neighbors to attend a workshop on his farm. His goal was to make this an annual event, expanding every year until it becomes a stable anchor for the growing collective of goat producers. The workshop was designed to introduce people to goat farming and teach those who already owned goats about best handling practices. ${ }^{5}$

The workshop began with a prayer in the recreational room of the small church across from the president's farm. Almost all Federation-related events begin and end with a prayer. The prayer is often used to remind the group of the overall goal and vision of the event to happen, and at times even used to encourage people to choose cooperation over and above their own individual ambitions. The prayer also reminds the participants to trust in a higher power and to devote themselves to this higher power through their pursuit of a better life. The prayers are often offered by a minister or pastor who is also a participant.

After the prayer, the president asked participants to stand up, introduce themselves, and discuss whether they had goats or were interested in getting goats. This icebreaker was aimed at building intimacy among the participants. It also instigated discussion among participants. In between introductions, the president told jokes and added comments. A light breakfast of beverages and pastries was served. The combined social exchanges and sharing of food were designed to create an informal atmosphere conducive to shared and

\footnotetext{
4 This ethnographic example is taken from my dissertation (Franzen, 2016).

${ }^{5} \mathrm{~A}$ video of portions of the workshop can be seen at https://vimeo.com/112238967/cb70dc20e3
}

equal communication among the participants.

Next, Federation field staff from Alabama offered a series of presentations on goat health and rearing, the techniques of silvopasture (combining goats with timber production), and the basics of cooperative development. These presentations included slides filled with technical information. The staff helped explain the technical details throughout the presentations and offered to meet individually with the farmers. Formal educational formats like this were often included with handson and demonstration forms of educational. At times, Federation staff invited extension agents or university researchers to make formal presentations during field days or on-farm workshops. As a result, many Federation-sponsored educational events involved hybrid forms of knowledge transmission, combining formal with informal, and didactic with experiential, forms of knowledge exchange.

After the morning activities, the participants moved to the president's nearby farm. On the farm, they were taught how to identify different breeds of goats, how to determine age, and how to examine the general health of male and female goats. One of the local farmers facilitated most of the training. He had been goat farming the longest, and therefore was considered the most knowledgeable among the group, even among the Federation staff. Along with basic identification, the local farmer facilitated hands-on training for the participants. He set up the goats to have their hooves trimmed and invited the participants to come and try trimming. Participants took turns approaching the goats, examining the hooves, and learning how to trim the hooves to the right length. During this time, both the farmer and Federation staff explained specific details about hoof trimming.

The experienced farmer also identified a goat that had grown a cyst and demonstrated how to drain the cyst safely. The participants observed the large amount of pus that oozed out of the drained wound and commented on the smell of the secretion. The farmer commented that despite its foulness, the smell was a normal sign that the cyst was simply an infection and would heal.

This on-farm training served as the core of the workshop. Although the beginning portion of the 
workshop communicated vast amounts of technical information, the on-farm portion enabled a sensory, tacit, and embodied form of knowledge accumulation. Participants spent time not only learning specific information about goats, but generally became more familiar with the sights, smells, sounds, and mannerisms of goats as they watched and participated in the handling of goats. Some of the participants also brought their children to the farm and encouraged them to touch and examine the goats, thus exposing the youth to the tacit aspects of goat farming. This familiarizing process is considered crucial among Federation members as a way to encourage youth to better understand farming in general and encourage their interest in farming. Such workshops did not necessarily teach youth agricultural skills, but rather created a sensory engagement through which youth began a tacit understanding of farming more generally.

The workshop was also a space for establishing the symbolic knowledge of a "good farmer." The experienced local farmer continually commented that the president was doing well and had learned to be a good farmer. These comments were meant to encourage the others to emulate his efforts. Being a "good farmer" in this case involved the productivity of his farm, the aesthetics of his goats, and also the care and attention the president gave to his operation. It also involved affirming that the subject position occupied by the president (that of a Southern African American farmer) could achieve the status of "good farmer." The recognition of the group, and of the Federation, provided a form of validity for farmers and a set of parameters by which to determine the qualities of a "good farmer."

The on-farm portion of the workshop also created an informal space for farmers to ask important questions of the Federation organizers. Specifically, some of the farmers had faced issues when applying to and receiving support from USDA-sponsored programs. This was a common concern brought up at several Federation events by farmers who had difficulty procuring grants, loans, or services from government or private institutions. The reasons ranged from overt discrimination, lack of Internet access, and convoluted application procedures, to failure to meet the qualifications. The organizers were familiar with these issues and aware of both overt and implicit forms of discrimination sometimes used to deny farmers full access to resources. The workshop provided a space for farmers and organizers to discuss the process of applying for USDA programs and obstacles farmers face when working with local agencies.

The workshop concluded back at the church with another meal and prayer, and stories. The president told stories about his youth and made jokes about how the participants were disciplined as children, thus aligning those present in a shared memory. He also spoke about his struggles beginning his goat farm and pointed to his current success after years of hard work. Overall, the workshop offered multiple forms of knowledge for new and beginning goat farmers and worked to build a stronger collective. Farmers received knowledge through diverse formats, including sensory and tacit knowledge. The prayers, meals, stories, and introductions all facilitated a collective and social connection between the participants, working to bring together individual farmers and building on their shared customs and cultural norms. Discussions on the structural barriers African American farmers faced also framed these as collective issues, and blended the technical aspects of goat farming with political-economic realities. As the president had hoped, he has continued to hold similar workshops on his property.

\section{Beginning Farmer Reality Tour 6}

In spring 2013, the Mississippi Association of Cooperatives (MAC), the Mississippi State Association of the Federation, hosted a Beginning Farmer Reality Tour to expose young and new farmers to the often unseen and unknown realities behind farming. The tour was designed as a series of visits to established farms over a two-day period. In addition to the visits to established farms, the tour incorporated a series of presentations from MAC staff, USDA agents, and a local farm-to-school

\footnotetext{
6 This ethnographic example is taken from my dissertation (Franzen, 2016).
} 
researcher. $^{7}$

This reality tour was a new educational initiative designed by MAC staff to fill what they saw as a deficit in the existing educational programs for new and beginning farmers. While many programs and trainings exist that are specifically geared toward field days, and farmer-to-farmer training is a familiar idea among farm extension services, this particular tour had a different undertone. The "reality" being exposed was more than just agricultural techniques and practices. Throughout the tour, the facilitators emphasized that this was a chance for beginning farmers to ask frank questions and learn about the social, economic, and political aspects that affect the lives of smallholding farmers, and especially African American farmers living in the U.S. South. The organizers felt that these sorts of conversations were often avoided in professional or public workshops and presentations. By creating an intimate setting, MAC organizers hoped the participants could have deeper discussions about existing realities.

Before the tour, the participants met in the MAC offices where the staff introduced them to the schedule of events and tour expectations. Most of the MAC staff consists of African American farmers, either actively working their own farms or assisting on family farms. They are familiar with the culture, language, and communicative style of rural farmers and were able to joke and cajole the participants as they discussed serious issues around finances and diverse income streams. For instance, one facilitator was encouraging the participants to consider rural tourism as a revenue stream. "They want to come, lay in the pasture, talk to the soil, and they're willing to pay [US]\$250 for two days," said the facilitator referring to rural tourists. These tourists desired the things farmers took for granted, such as being outdoors, touching animals, and working under the sun. But the reasons that African American farmers were not able to tap into this industry, according to the facilitator, was that they were unfamiliar with the opportunities, their parents were too skeptical, and they were not on

${ }^{7}$ A video of portions of the tour can be seen at https://vimeo.com/91238506/89a624afaf the Internet. The facilitator's familiarity with the common family structures of the participants, the influence of older generations on managing the farm, and the lack of Internet access among the participants helped her lay out the economic obstacles around small-holding farming in a way that was relevant for the participants.

In discussing the economics of small-holding farming, the facilitator also broke down how much monthly and yearly income could be earned from a five-acre (2-hectare) plot growing vegetables and goats. Her example was based on a real farmer whose books she helped manage. The facilitator was promoting to beginning farmers how maintaining only a small farm, or even just a garden plot, could be beneficial. In the face of industrial agriculture's emphasis on scaling up, many Federation organizers see a benefit in farmers maintaining small plots. If small plots are able to provide at least supplemental income, rural residents can simultaneously improve their livelihoods, better sustain their landholdings, and continue a farming tradition. Part of the effort of this tour was to highlight the benefit of small farmers and promote the continuance of small-holding farming.

The tour consisted of visits to several farms during which participants explored the crops, animals, equipment, and techniques of the established farmers, who offered informal presentations and time for open discussion. Presentations offered by established farmers focused not just on knowledge, but on processes of knowledge accumulation. Each spoke of methods of gaining new knowledge and of pitfalls and obstacles new farmers, especially African American farmers, may face. For instance, one established farmer encouraged the beginning farmers to read farm magazines, attend conferences, and, most importantly, to learn from their elders. He equated these diverse forms of knowledge gathering with college, emphasizing that new farmers did not necessarily need formal education but rather could build their knowledge through a combination of experience, apprenticeship, and public resources.

Similarly, another farmer on the tour questioned the efficacy of a college education and asked the participants how many had been given the wrong kind of information in school, or just 
enough "to hang" themselves. Slowly, the whole crowd began to raise their hands, jointly admitting that so-called "educational" spaces may in fact be detrimental for their success. But he did not just warn about dominant educational spaces; he also pointed out that African American farmers may be hesitant to share information with each othersomething they all needed to work to overcome. As he explained, "Black men are afraid to pass on information, afraid I'm going to get a little too much." But if farmers learned to help one another, there is a better chance of success for the whole group.

This farmer was encouraging a collectivist approach to farming, an approach that is not supported or encouraged within the industrial agricultural paradigm. The collectivist approach was a means to not only help farmers with smaller acreages, but also to help African American farmers access capital. African American farmers' operations were often behind their white counterparts due to lack of capital, resulting in an inability to create value-added products, withstand unforeseen circumstances, or own their means of production. A collective approach would provide both power and resources to small-holding African American farmers. The dilemma, according to many of the farmers on the tour, was that in order to cultivate a collectivist attitude, African Americans needed to have pride in the act of farming. The farmers on the tour similarly emphasized that farming was about passion and freedom, not status or wealth. These social, economic, and political goals were not part of typical extension agendas. The tour provided a space to bring forth complex issues that African American farmers face and discuss different systemic approaches to agriculture.

The general tenor of conversations with established farmers framed new farmers as capable agents who needed to understand their social, political, and economic environments while simultaneously learning key farming techniques and various levels of tacit knowledge to become what one cattle farmer called a "physical farmer." This farmer began explaining that the university extension programs now promoted computerized farming, or what is being called precision farming, which reduces farming to a set of calculations based on precise variables. Physical farming, meanwhile, is the type of farming based on a continuous presence and observation of the fields where tacit knowledge is gained through continued experience so that eventually small details are combined to understand comprehensive patterns. This enables farmers to understand how to address the constantly shifting patterns and relationships involved in farming. As he was about to discuss these issues further, he promptly turned to me and told me to turn off the camera. His decision to keep this part of the conversation off the record furthered the overall agenda of this tour, which was designed to support and evoke conversations that may have political or social consequences but were important nonetheless for beginning farmers.

The tour uniquely addressed the needs of African American beginning farmers through different educational strategies. Firstly, diverse types of knowledge were presented by the established farmers. Along with specific techniques, the established farmers divulged insights into the process of gaining knowledge, attitudinal challenges, political obstacles, and continuing issues of racism. After conversations with each established farmer, the participants spent time on each farm gaining sensory knowledge of the crops, animals, machinery, and general set-up of existing farms. Secondly, the form of communication used in the tour differed from typical extension programs. Not only were the established farmers communicating in informal, local vernaculars, but also the push by MAC organizers for more frank conversations led to a number of intimate conversations. Finally, the established farmers emphasized a systemic analysis of appropriating and incorporating knowledge. They did not categorically reject any form or institution of education. Rather, they cautioned the farmers to think carefully about their own goals and paradigms for farming, and to use this to govern which methods, techniques, and information they would adopt into their own practices.

This tone was contrasted by the supplemental presentations offered by two USDA agents and a university researcher who focused on farm-toschool issues. Each of these presenters spoke from their own respective positions-as government agents or from within the school system. The 
farmers were tasked with the duty of conforming to the positions deemed appropriate by these institutions. For example, the woman who presented on farm-to-school initiatives spoke about the regulations and obstacles involved with supplying local schools with local food. Ultimately, the food service director of the school system controls these decisions, so the researcher urged farmers to understand how to best work with the director. They would need to find ways to appeal to the director, such as offering to make presentations at the school to show examples of local farmers, offering taste tests of their produce, or creating biographies with photographs for the schoolsa strategy the researcher emphasized as part of the pilot program in the local school district, where children could view the biographies while waiting in line in the hallway of the school cafeteria. Her point was that farmers needed to brand themselves as the right kind of farmers and to make this branding available for use by schools and attractive to the director. The researcher also stressed the need for uniform, reliable, and timely food products branded with an ideal image of "good local food" and appropriately packaged to fit school lunch needs. Her slideshow supported her assertions by showing pictures of happy children eating wholesome food.

The USDA agents similarly offered detailed presentations on the specific regulations of different government programs that may be of interest to the new farmers, such as the program that partially funds farmers' hoop houses. These presentations were offered in a communicative style vastly different from the conversations among farmers. The tone, language, and style were all drawn from the agents' experiences as professionals. The information was directly communicated without story or interpretation. A vast amount of details were listed linearly to an audience that did not have any form of note-taking materials. Some of the MAC staff present took handouts from the USDA agents so that they could help the individual farmers later.

The tour highlighted the expectations placed on different groups' communicative capacities. Those who use the dominant discourse rarely feel a need to actively interpret diverse linguistic frame- works. By contrast, users of minority discourses are not only frequently expected to adapt to and utilize diverse sets of communicative capacities, but their skill in doing so is commonly overlooked. Agricultural knowledge is often taught using the dominant discourse, and diverse farmers who fail to accurately respond to or utilize the information are seen as having a lack of motivation, apathy, intellect, or awareness. What was unique about the Reality Tour was not necessarily the informational content, but the contextualization of knowledge and communicability of knowledge exchanges.

This tour was organized because the staff at MAC felt that young potential farmers were having difficulty learning how to begin their farming enterprises. Many of the member cooperatives that are part of MAC have discussed the need to recruit younger members, both to help sustain the cooperatives and to retain existing African Americanowned land and rural communities. ${ }^{8}$ Throughout informal conversations before, during, and after the two-day tour, participants admitted that this program had been extremely useful in a way that other educational programs had not been. Participants felt more aware of the realities around initiating a farming enterprise. MAC evaluated their program as successful due to the fact that after the tour, two participants continued to work with the MAC staff in order to apply for a governmentsponsored loan to purchase land and begin a cattle farm. The MAC staff is committed to repeating this tour for other new and beginning farmers in hopes of continuing to encourage them to take the first steps in initiating their agricultural enterprises.

\section{Discussion and Conclusion}

This paper used a framework of communicability to examine the process of knowledge transmission within agricultural education using case studies from the Federation. These examples offer four key points. First, they show the process of knowledge exchange using local communicative frameworks. In the examples discussed here, the shared communicative frameworks exist largely due to the

\footnotetext{
8 This information is based on discussions held at cooperative meetings and at the MAC annual meeting.
} 
cultural, social, historic, and linguistic frameworks shared between educators and participants. Many educational events utilize farmer-to-farmer forms of knowledge transfer as well. However, even Federation staff who are not from the communities they serve spend considerable time on both a professional and personal level getting to know local communities and familiarizing themselves with local frameworks of communication. Federation educators also serve as "translators," sharing knowledge from other sources within local communicability spheres. This issue of communicability in agricultural education is critical in disseminating information and knowledge and may become even more important as knowledge about climate change and adaptability need to be communicated to diverse populations. The ability of educators, or intermediaries, to communicate knowledge not only within local languages, but also within local communicative frameworks, is essential for knowledge transfer.

Second, these examples show that farmer-tofarmer forms of knowledge transfer are also useful for transmitting tacit and symbolic knowledge. Even at a cursory level of exposure, this type of knowledge familiarizes the senses with an awareness of some of the cues and factors essential in the process of farming. For new and beginning farmers, this type of familiarity can build confidence and awareness of how to take on new agricultural tasks. Witnessing the success of farmers holding similar identities can also provide symbolic knowledge about what it means to be a farmer, and who can occupy that position.

Third, the Federation's efforts show that communicability spheres are crucial factors in considering justice in the agricultural system. There is an increasing awareness of ongoing injustices in the food system and the role education plays in providing a means to understand and address these injustices. However, there has also been growing criticism of food justice efforts that assume a subject position of whiteness (for instance, see Guthman, 2008). If education itself is transmitted through communicability spheres that exclude specific subjective identities, then education can continue to cause and exacerbate problems of injustice and exclusion. The Federation's forms of education create communicability spheres designed to support and empower African American farmers.

Fourth, another crucial component in considering how to make a fair and equitable agricultural system is understanding how knowledge is embedded within specific cultural, political, and ecological frameworks. The U.S. has had a history of promoting industrial agriculture, resulting in a "get big or get out" phenomenon as farms become more efficient and mechanized. But other values are at play within the agricultural system. Many of the Federation members expressed their desire to create small, sustainable farms that would provide supplemental income and serve as a means to protect their farming traditions, maintain their landholdings, and support their rural communities. Industrialized agricultural knowledge is not suited to helping support these values. The Federation helps train farmers to build agricultural enterprises that support their diverse values. They also serve as an intermediary organization by communicating the needs of their members to larger institutions, such as the U.S. Department of Agriculture, and helping their members find existing programs that may serve their needs and goals.

This research suggests two approaches to improving the inclusiveness, equity, and effectiveness of agricultural education. First, agricultural educators should consider the importance of communicability in shaping the process of knowledge transfer. Outside educators are unlikely to ever fully grasp or perfectly utilize local discourses, performances, and contextualization. Yet strategies may be enacted to help facilitate agricultural extension. Being aware of communicative competencies and putting effort toward learning others' communicative patterns, including style, idioms, norms, and traditions, will help facilitate better engagement. Also, being aware of the subjective positions and identity roles that communication creates will help extension agents address assumptions and biases.

While this type of awareness would improve agricultural education, the complex aspects of communication cannot be overcome easily. Therefore, the second recommendation is the use of individuals or groups that can translate between 
different communicative frameworks and that are also familiar with both expert-derived and local knowledge, institutions, and discourses (Eversole, 2012). Grassroots organizations play an important role in determining the needs of local communities and facilitating educational programs that fill the needs and goals of local farmers while engaging in local spheres of communicability. Even the Federation advocates for local educational programs within its own network. While it maintains centralized programs, it also recognizes and supports educational programs implemented by State Associations and member cooperatives.

The Federation has served to fill gaps in education for African American farmers by facilitating physical access to knowledge and resources, as well as by facilitating access to the communicability spheres through which mainstream agricultural knowledge is transmitted. The Federation also created its own educational programs in order to meet the unique needs of African American farmers. As African American farmers have become more visible to extension agencies and gained more access to mainstream educational resources, it may seem that the Federation's role is diminishing, but intermediary organizations such as the Federation are important beyond their ability to make physical connections. Because it focuses on the role of communicability, the Federation's role is still crucial for meeting the needs of African American farmers.

\section{References}

Briggs, C. L. (2005). Communicability, racial discourse, and disease. Annual Review of Anthropology, 34, 269291. http://dx.doi.org/10.1146/annurev.anthro. $\underline{34.081804 .120618}$

Bucholtz, M., \& Hall, K. (2005). Identity and interaction: A sociocultural linguistic approach. Discourse Studies, 7(4-5), 585-614. https://dx.doi.org/10.1177/1461445605054407

Burawoy, M. (1998). The extended case method. Sociological Theory, 16(1), 4-33. https://doi.org/10.1111/0735-2751.00040

Burton, R. J. F. (2004). Seeing through the 'good farmer's' eyes: Towards developing an understanding of the social symbolic value of 'productivist' behaviour. Sociologia Ruralis, 44(2),
195-215. http://dx.doi.org/10.1111/j.14679523.2004.00270.x

Cowan, T., \& Feder, J. (2013). The Pigford cases: USDA settlement of discrimination suits by Black farmers (RS20430). Wasington, D.C.: Congressional Research Service. Retrieved from http://nationalaglawcenter.org/wp-content/ uploads/assets/crs/RS20430.pdf

Csordas, T. J. (1993). Somatic modes of attention. Cultural Anthropology, 8(2), 135-156. http://dx.doi.org/10.1525/can.1993.8.2.02a00010

Daniel, P. (2013). Dispossession: Discrimination against African American farmers in the age of civil rights. Chapel Hill: The University of North Carolina Press.

Dienderen, A. (2007). Performing urban collectivity: Ethnography of the production process of a community-based film project in Brussels. In S. Pink (Ed.), Visual interventions: Applied visual anthropology (pp. 247-270). New York: Berghahn.

Elder, S. (1995). Collaborative filmmaking: An open space for making meaning, a moral ground for ethnographic film. Visual Anthropology Review, 11(2), 94-101.

http://dx.doi.org/10.1525/var.1995.11.2.94

Eversole, R. (2010). Remaking participation: Challenges for community development practice. Community Development Journal, 47(1), 29-41. https://doi.org/10.1093/cdj/bsq033

Fabian, J. (2001). Anthropology with an attitude: Critical essays. Stanford, California: Stanford University Press.

Federation of Southern Cooperatives/Land Assistance Fund [FSC/LAF]. (n.d.). History. Retrieved February 21, 2010, from http://www.federation southerncoop.com/history.htm

Flores, C. Y. (2007). Sharing anthropology: Collaborative video experiences among Maya filmmakers in post-war Guatemala. In S. Pink (Ed.), Visual interventions: Applied visual anthropology (pp. 209-226). New York: Berghahn.

Franzen, S. M. (2016). Visualizing possibilities: Rural development strategies among African American farmers in the Southeastern US (Doctoral dissertation). Emory University, Atlanta, Georgia. http://pid.emory.edu/ark:/25593/rhmw7

Glickman, D., Rominger, R., \& Reed, P. (1997). Civil rights at the United States Department of Agriculture: $A$ report by the Civil Rights Action Team [CRAT Report]. Washington, D.C.: USDA. 
Grim, V. (1996). Black participation in the Farmers Home Administration and Agricultural Stabilization and Conservation Service, 1964-1990. Agricultural History, 70(2), 321-336. http://www.jstor.org/stable/3744540

Grimshaw, A., \& Ravetz, A. (2009). Observational cinema: Anthropology, film, and the exploration of social life. Bloomington: Indiana University Press.

Guthman, J. (2008). Bringing good food to others: Investigating the subjects of alternative food practice. Cultural Geographies, 15, 431-447. http://dx.doi.org/10.1177/1474474008094315

Harris, C. V. (2008). "The Extension Service is not an integrated agency": The idea of race in Cooperative Extension Service. Agricultural History, 82(2), 193 219. http://dx.doi.org/10.3098/ah.2008.82.2.193

Hart, T. R., (2001). Something lost: The Black farmer and the Alabama Cooperative Extension Service before, during, and after integration. Southern History, 22, 55-65.

Hymes, D. H. (1985). Toward linguistic competence. AIL A Review/Revue de l'AIL A, 2, 9-23. Retrieved from http://www.aila.info/download/publica tions/review/AILA02.pdf

Jones, H. S. (1994). Federal agriculture policies: Do Black farm operators benefit? Review of Black Political Economy, 22(4), 25-50. http://dx.doi.org/10.1007/BF02689978

MacDougall, D. (1998). Transcultural cinema. Princeton, New Jersey: Princeton University Press.

MacDougall, D. (2003). Beyond observational cinema. In P. Hockings (Ed.), Principles of visual anthropology (pp. 115-132). Berlin: Mouton de Gruyter.

MacDougall, D. (2006). The corporeal image: Film, ethnography, and the senses. Princeton, New Jersey: Princeton University Press.
Polanyi, M. (1966). The tacit dimension. London: Routledge \& Kegan Paul.

Rouch, J., \& Feld, S. (Trans.). (2003). Ciné-ethnography. Minneapolis: University of Minnesota Press.

Sherzer, J. (1987). A discourse-centered approach to language and culture. American Anthropologist, 89(2), 295-309. http://dx.doi.org/10.1525/aa.1987.89.2.02a00010

Shotwell, A. (2011). Knowing otherwise: Race, gender, and implicit understanding. University Park: Pennsylvania State University Press.

Sjöberg, J. (2008). Ethnofiction: Drama as creative research practice in ethnographic film. Journal of Media Practice, 9(3), 229-242. https://doi.org/10.1386/jmpr.9.3.229_1

Streeck, J., Goodwin, C., \& LeBaron, C. (Eds.). (2011). Embodied interaction: Language and body in the material world. New York: Cambridge University Press.

Whayne, J. M. (1998). Black farmers and the Agricultural Cooperative Extension Service: The Alabama experience, 1945-1965. Agricultural History Society, 72(3), 523-551.

http://www.jstor.org/stable/3744569

Wood, S. D., \& Gilbert, J. (2000). Returning African American farmers to the land: Recent trends and a policy rationale. The Review of Black Political Economy, 27(4), 43-64. http://dx.doi.org/10.1007/BF02717262

Young, C. (2003). Observational cinema. In P. Hockings (Ed.), Principles of Visual Anthropology (pp. 99-114). Berlin: Mouton de Gruyter.

Zippert, J. (1979). Memorandum: Proposal for FSC rural training and research center. The Federation of Southern Cooperatives Collection, Amistad Research Center at Tulane University, New Orleans, Louisiana. 